\title{
Epidemiology of urolithiasis consultations in the Paraíba Valley
}

\section{Epidemiologia dos atendimentos por urolitíase no Vale do Paraíba}

\author{
Guilherme Ricardo Nunes Silva'; Luiz Carlos Maciel.
}

\begin{abstract}
A B S T R A C T
Objective: to know the epidemiological profile of patients with urolithiasis in the Paraiba Valley region, identifying its prevalence and spatial distribution. Method: we conducted a cross-sectional study, by residence location in the Paraiba Valley, on morbidity data due to urolithiasis obtained from the DATASUS, covering the period between 2010 and 2012. We aimed at identifying the general, male and female prevalence of urolithiasis, the distribution by age, type of visit, year season and spatial distribution. Results: there were 1,901 visits for urolithiasis in the 35 municipalities of the Paraiba Valley in the three years studied, 52.3\% of them of female patients. Of the total, $70.1 \%$ of the visits were emergency ones. The feminine visits $(67.2 \%)$ were mostly also urgent $(p<0.01)$. The overall prevalence for urolithiasis was 31.7/100,000. Male prevalence was 30.7/100,000, and the female, 32.7/100,000 ( $p>0.05$ ). The prevalence ratio was 0.9 men for every woman. The age group with the highest prevalence was between 30 and 39 years, with $23.1 \%$. Warm seasons concentrated $51.6 \%$ of cases, while $48.8 \%$ occurred in the cold ones (p>0.05). Conclusion: women are more affected by urolithiasis than the male in the Paraiba Valley region, an unprecedented in the literature. There was no relationship between the year season and the disease. We identified municipalities where preventive actions of urinary lithogenesis are required.
\end{abstract}

Keywords: Urology. Urolithiasis. Epidemiology.

\section{INTRODUCTION}

U olithiasis is one of the most frequent diseases of the urinary tract in the world, displaying an increase in incidence and prevalence in all age groups and genders in the last decades, especially in industrialized countries ${ }^{1-3}$. It determines large costs for the health care systems in the world. In 2000, the estimated treatment cost of urolithiasis was more than two billion dollars in the United States ${ }^{4}$. In 2012, the Brazilian Unified Health System (SUS) has spent more than 32.5 million reais on hospital visits and admissions due to urolithiasis in Brazil ${ }^{5}$.

The epidemiological and lithogenic factors of urolithiasis involve ethnicity, gender, age, nutritional and dietary aspects, climate, occupation and physical activity, and it is known to be more common in diabetic, hypertensive and obese patients ${ }^{2,3,6}$. The peak incidence occurs between 20 and 50 years, decreasing after 70 years, being uncommon in children under ten years. Whites are three times more likely to develop urolithiasis that blacks, while Hispanics and Asians have intermediate risk. By mainly affecting people in the economically active group, it is a major cause of absenteeism, affecting the patients' professional productivity. Studies suggest that the incidence of symptomatic urolithiasis increases during the summer, since the increase in temperature and exposure to sunlight are important risk factors for urinary lithogenesis, by favoring a greater risk of dehydration, resulting in increased urinary concentration and increased possibility of formation of urinary calculi and its clinical manifestations 2,6-8. $^{2}$.

Historically, urolithiasis has been two to three times more common in men than in women, reaching the men-woman ratio of 3-2,6,7. However, alterations in food consumption patterns, fluid intake and obesity in men and women can cause changes in urolithiasis incidence and prevalence. In the United States the prevalence of urolithiasis is one in every 11 people, and the possibility of the male and female population develop urinary calculi during life is $12 \%$ and $6 \%$, respectively ${ }^{6,9}$. Recent studies suggest that this epidemiological relationship between male and female is changing. An annual increase of women calls with complaints related to urolithiasis in emergency units was found, with decreasing male predominance in this disease. The incidence of urolithiasis in the United States,

1 - University of Taubaté, Department of Medicine, Taubaté, SP, Brazil. 
for example, is currently 1.3 men for every woman ${ }^{9-11}$. Currently there are no epidemiological studies on the profile of patients seen due to urolithiasis in Brazil.

Changes in the incidence and prevalence of urolithiasis may reflect underlying changes in the disease's risk factors. By identifying changes in its epidemiological pattern, new avenues for the prevention and better care for patients with this disease can be elucidated. This study aims to evaluate the epidemiological profile of the patients treated for urolithiasis in the Paraíba Valley region.

\section{METHODS}

This is a cross-sectional study with urolithiasis morbidity data by residence location in the 35 municipalities of the Paraíba Valley region, State of São Paulo, in the period between 2010 and 2012. We obtained data from the National Health System DATASUS database. We excluded the coastal municipalities (Caraguatatuba, Ubatuba, Ilhabela and São Sebastião) from the study because they are geographically separated from the others by the Serra do Mar (Sea Hills).

We considered the population living in the municipalities in the years 2010 to 2012, with the diagnoses N20 to N23 (kidney and ureter calculi, lower urinary tract calculi, urinary tract calculi in diseases classified elsewhere, unspecified renal colic) of the International Statistical Classification of Diseases and Related Health Problems, tenth revision (ICD-10) ${ }^{12}$.

We analyzed the data to identify the overall prevalence of symptomatic urolithiasis per 100,000 inhabitants, the prevalence by gender, the age group of patients treated, the type of care (elective or emergency), the season when hospitalizations occurred and the spatial distribution of urolithiasis visits by municipality in which the patient lived. The months considered representatives of the seasons summer (January, February and March), autumn (April, May and June), winter (July, August and September) and spring (October, November and December) are in agreement with data obtained at the Information Access Portal of the National Institute of Meteorology (INMET), for the three years.
We analyzed data using spatial statistics, being geo-referenced and analyzed by area to provide the Global Moran indices (I), with the TerraView software, provided by the National Institute for Space Research (INPE). The Global Moran index is a first order measure of spatial autocorrelation, which indicates the degree of spatial association in the set of information through the product relative to the average. After assembly of the thematic maps with the urolithiasis general, male and female prevalence, we evaluated the expected spatial distribution by Local Empirical Bayesian Method. This performs a softening of rates by municipality, assuming that the knowledge and uncertainties about the real risk value of an event in each area within a given region may be represented by a probability distribution ${ }^{13}$. With the achievement of the expected rates by the local empirical Bayes method, we then compared these with the actual prevalence rates found.

\section{RESULTS}

During the study period, urolithiasis complaints were responsible for 1,901 calls from residents in the 35 municipalities of the Paraíba Valley, ranging from one to 562. Of these, 665 (35\%) occurred in 2010, 612 $(32.2 \%)$ in 2011 and 624 (32.8\%) in 2012. The average was 54.3 attendances, with a standard deviation of 107.8. During the three years, $52.3 \%$ (995) of visits were from female patients. Of the 906 calls by male patients, 73.3\% (664) were on an emergency basis. In females, of the 995 urolithiasis calls, $67.2 \%$ (668) were urgent $(p<0.01)$.

The prevalence of symptomatic urolithiasis in Paraíba Valley, obtained indirectly by the number of visits resulting from this disease, was 31.7/100,000. Regarding gender, the prevalence was $30.7 / 100,000$ in men and $32.7 / 100,000$ in women ( $p>0.05$ ). The relationship found between the male and female prevalence was 0.9 men for every woman affected with the disease. During the period, the age group with the highest number of patients was between 30 and 39 years, with 439 calls, equivalent to $23.1 \%$ of the total demand in the three years. Of the total demand due to urolithiasis, $45.1 \%$ occurred in patients aged between 30 and 49 years. 
In the summer, there were 517 due to urolithiasis, corresponding to $27.2 \%$ of the total. In the fall, there were 460 (24.2\%). In winter, the number of urolithiasis treatments was 461 (24.2\%). Finally, in the spring, there were $463(24.4 \%)$ calls. In the warm seasons (spring and summer) calls summed $51.6 \%$ (980) ( $p>0.05)$. The global Moran index (MI) and the $p$-value were $I_{M}=0.01(p=0.43)$ for urolithiasis calls per 100,000 inhabitants. Table 1 brings the general and by-gender prevalence of symptomatic urolithiasis of all 35 studied municipalities.

Applying the estimated Bayesian Local Empirical method, we found differences in the actual general prevalence from that expected. The $I_{M}$ and its p-value were respectively 0.08 and 0.13 . We computed the same estimate of the Bayesian Local Empirical method for the prevalence of symptomatic urolithiasis by gender. In men, the $I_{M}$ was 0.17 , and its $p$-value, 0.07 . For females, the $I_{M}$ was 0.11 , and $p=0.1$.

\section{DISCUSSION}

This study on the epidemiology of urolithiasis has identified the profile of the distribution of the disease in Paraíba Valley and its prevalence by gender, age, type of service and the season with the most calls. Urolithiasis is historically more prevalent in men than in women. In a review of the specific aspects of male and female genders that are related to the genesis of urolithiasis, Seitz et al. ${ }^{3}$ stressed that urinary osmolality in men is higher than in women. Furthermore, the antidiuretic response to vasopressin is different between genders, being greater in males, which can influence the urinary concentration and therefore result in a higher chance of urinary stone formation. For years urolithiasis researchers have realized the trend of change in its incidence and prevalence, especially by the gradual increase in the care of women, with consequent reduction of the relationship between male/ female care cr,11,14-17. $^{3}$.

The prevalence of urolithiasis found in our region is different from all the other identified in similar studies. We found a prevalence in which the female gender is the majority, an unprecedented event. In
Table 1. Overall and by gender $/ 100,000$ prevalence of symptomatic urolithiasis in residents of the 35 municipalities of the São Paulo State Paraiba Valley between 2010 and 2012.

\begin{tabular}{|c|c|c|c|}
\hline Variables & Overall & Male & Female \\
\hline Aparecida & 10.5 & 9.9 & 11.0 \\
\hline Arapeí & 40.3 & 79.8 & 0 \\
\hline Areias & 9.0 & 18.2 & 0 \\
\hline Bananal & 13.0 & 19.7 & 6.4 \\
\hline Caçapava & 10.9 & 12.6 & 9.3 \\
\hline Cachoeira Paulista & 41.8 & 53.8 & 30.2 \\
\hline Campos do Jordão & 43.0 & 31.2 & 54.3 \\
\hline Canas & 15.0 & 14.8 & 15.2 \\
\hline Cruzeiro & 47.4 & 46.1 & 48.7 \\
\hline Cunha & 139.3 & 132.0 & 147.0 \\
\hline Guaratinguetá & 51.8 & 55.3 & 48.5 \\
\hline Igaratá & 45.1 & 73.4 & 15.4 \\
\hline Jacareí & 34.5 & 38.8 & 30.3 \\
\hline Jambeiro & 6.1 & 0 & 12.7 \\
\hline Lagoinha & 27.6 & 26.9 & 28.3 \\
\hline Lavrinhas & 35.2 & 20.0 & 50.6 \\
\hline Lorena & 33.4 & 35.8 & 31.1 \\
\hline Monteiro Lobato & 16.0 & 0 & 33.5 \\
\hline Natividade da Serra & 40.1 & 28.8 & 52.4 \\
\hline Paraibuna & 17.2 & 18.8 & 15.6 \\
\hline Pindamonhangaba & 27.1 & 26.9 & 27.4 \\
\hline Piquete & 9.5 & 4.9 & 13.8 \\
\hline Potim & 16.8 & 14.9 & 19.3 \\
\hline Queluz & 14.5 & 11.4 & 17.7 \\
\hline Redenção da Serra & 34.5 & 16.6 & 54.2 \\
\hline Roseira & 34.4 & 27.3 & 41.7 \\
\hline Santa Branca & 12.1 & 0 & 24.1 \\
\hline $\begin{array}{l}\text { Santo Antônio do } \\
\text { Pinhal }\end{array}$ & 20.5 & 10.2 & 31.0 \\
\hline $\begin{array}{l}\text { São Bento do } \\
\text { Sapucaí }\end{array}$ & 76.4 & 75.9 & 76.9 \\
\hline $\begin{array}{l}\text { São José do } \\
\text { Barreiro }\end{array}$ & 16.4 & 16.3 & 16.5 \\
\hline $\begin{array}{l}\text { São José dos } \\
\text { Campos }\end{array}$ & 29.4 & 28.1 & 30.7 \\
\hline $\begin{array}{l}\text { São Luíz do } \\
\text { Paraitinga }\end{array}$ & 60.9 & 62.7 & 59.1 \\
\hline Silveiras & 11.4 & 11.3 & 11.6 \\
\hline Taubaté & 27.3 & 22.5 & 31.9 \\
\hline Tremembé & 22.5 & 9.1 & 37.5 \\
\hline
\end{tabular}

Source: DATASUS. 
Table 2, we compare the prevalence of urolithiasis between male and female found in several studies on its prevalence.

Regarding the type of call, it became clear that the most common call is the urgent one, given that, when symptomatic, urolithiasis usually presents with intense pain and signs that compromise quality of life ${ }^{6,18}$. Women were more prevalent, both in elective and in emergency care $(p<0.01)$.

We found that $45.1 \%$ of patients treated during the study period were aged between 30 and 49 years, in agreement with the literature ${ }^{3,15}$. According to Trinchieri et al. ${ }^{19}$, the overall incidence of urolithiasis increases about $0.4 \%$ per year, $0.6 \%$ in males and $0.2 \%$ in females. According to their study, the annual increase in urolithiasis is probably a result of interaction between environmental factors such as dietary habits and lifestyle, particularly the increase in the consumption of animal protein.

When analyzing calls for urolithiasis by season, it became clear that most of the visits occurred in the summer, in which there is greater risk of dehydration due to the increased average temperature, which predisposes to increased urinary concentration and greater chance of urinary calculus formation. However, when comparing the attendances in the warm seasons (spring and summer) with the cold ones (fall and winter), there was no statistical significance ( $p>0.05$ ). In a study on the influence of geographical variation in the prevalence of urolithiasis, Soucie et al. ${ }^{20}$ concluded that the ambient temperature and the intensity of sunlight are important factors in the genesis of urolithiasis. They observed that the risk of a person developing urinary calculi is almost twice higher in the residents of states nearby the equator, and therefore warmer and with higher incidence of sunlight, when compared with those closer to the north pole, with lower average temperatures and lower sunlight incidence.

The prevalence of symptomatic urolithiasis in Paraíba Valley in the three years studied was $31.7 / 100,000$, fewer than the one found in Florida, in 2004, by Strope et al. ${ }^{11}$, of $169.9 / 100,000$. In the same study, the prevalence of symptomatic urolithiasis in males and females were, respectively, 105.5 and $64.4 / 100,000$. In our study, the prevalence was $30.7 / 100,000$ for males and 32.7/100,000 for females. No municipality in the studied region showed a higher overall prevalence than that found by Strope et al. ${ }^{11}$, however the municipality of Cunha had a higher male prevalence than the one found in that study, and as the female prevalence, again Cunha and also São Bento do Sapucaí had a prevalence higher than that found in Florida (Table 1).

Upon spatial analysis, the municipalities with the highest prevalence of urolithiasis in the Paraíba Valley were evident. When considering both genders, there was a cluster of municipalities represented by Sao Luiz do Paraitinga, Cunha, Guaratinguetá, Campos do Jordão and Sao Bento do Sapucaí. For the prevalence in males, the predominant cluster of municipalities was formed by São Luiz do Paraitinga, Cunha and Guaratinguetá. For females, the municipalities belonging to the higher prevalence cluster were Redenção da Serra, Natividade

Table 2. Urolithiasis male/female prevalence ratio. Adapted from Seitz et al. ${ }^{3}$.

\begin{tabular}{lcc}
\hline & Male/female prevalence ratio & \\
\hline Daudon et al. ${ }^{14}$ & $2.3(2001)$ & France \\
Knoll et al. ${ }^{15}$ & $2.4(1977)$ & Germany \\
& $2.7(2006)$ & United States \\
Nowfar et al. ${ }^{16}$ & $1.6(1998)$ & \\
Lieske et al. ${ }^{17}$ & $1.2(2003)$ & United States \\
Our study & $3.1(1970)$ & Brazil \\
\hline
\end{tabular}


da Serra, Sao Luiz do Paraitinga, Cunha, Guaratinguetá, Campos do Jordao and São Bento do Sapucaí. These clusters represent municipalities where intervention is important for reducing urolithiasis incidence and prevalence. After evaluation of the municipalities by the Empirical Bayesian Local method, it was possible to see differences in the spatial distribution of the general, male and female symptomatic urolithiasis, which may mean an underreporting of urinary calculi cases or even bad filling of health services forms by staff, not respecting the patient's municipality of residence.
In conclusion, the epidemiological and spatial analysis of urolithiasis in the Paraíba Valley has identified that in the area in question, the women seem to be more affected than men are. We did not detect a relationship between the season and disease. It was possible to identify cities with the highest prevalence rates, where an intervention is required to reduce the occurrence of urolithiasis. For the epidemiological evaluation of urolithiasis in Brazil to be possible, further studies in other Brazilian regions are needed.

\title{
R E S U M O
}

\begin{abstract}
Objetivo: conhecer o perfil epidemiológico dos pacientes com urolitíase, na região do Vale do Paraíba, identificando sua prevalência e distribuição espacial. Métodos: estudo transversal com dados de morbidade por local de residência decorrente de urolitíase no Vale do Paraíba, relativos ao período compreendido entre 2010 e 2012, obtidos do DATASUS. Os dados foram analisados para identificar a prevalência geral, masculina e feminina da urolitíase, a distribuição por idade, tipo de atendimento, estação do ano e sua distribuição espacial. Resultados: ocorreram 1901 atendimentos por urolitíase nos 35 municípios do Vale do Paraíba nos três anos estudados, sendo $52,3 \%$ dos pacientes do sexo feminino. Do total, 70,1\% dos atendimentos foram em caráter de urgência. Os atendimentos femininos, na sua maioria $(67,2 \%)$, também foram de urgência $(p<0,01)$. A prevalência geral encontrada para a urolitíase foi 31,7/100.000 habitantes. A prevalência masculina foi 30,7/100.000 e a feminina de 32,7/100.000 ( $p>0,05$ ). A relação de prevalência encontrada foi 0,9 homens para cada mulher. A faixa etária com o maior número de pacientes atendidos foi entre 30 e 39 anos, com $23,1 \%$ do total. Nas estações quentes ocorreram $51,6 \%$ dos atendimentos, enquanto nas frias $48,8 \%$ ( $p>0,05)$. Conclusões: foi possível identificar que na região do Vale do Paraíba o sexo feminino é mais acometido pela urolitíase do que o masculino, fato inédito na literatura. Não se encontrou relação entre a estação do ano e a doença. Foram identificados municípios onde ações de prevenção da litogênese urinária são necessárias.
\end{abstract}

Descritores: Urologia. Urolitíase. Epidemiologia.

\section{REFERENCES}

1. Stoller ML. Urinary stone disease. In: Tanagho EA, McAninch JW, editors. Smith's General Urology. 17th ed. New York: McGraw-Hill; 2008. p. 246-90.

2. Knoll T. Epidemiology, pathogenesis, and pathophysiology of urolithiasis. Eur Urol. 2010;12 Suppl 9:S802-6.

3. Seitz C, Fajkovic H. Epidemiological gender-specific aspects in urolithiasis. World J Urol. 2013;31(5):1087-92.

4. Eaton SH, Cashy J, Pearl JA, Stein DM, Perry K, Nadler RB. Admission rates and costs associated with emergency presentation of urolithiasis: analysis of the Nationwide Emergency Department Sample 2006-2009. J Endourol. 2013;27(12):1535-8.

5. Brasil. Ministério da Saúde. Datasus. Morbidade hospitalar do SUS por local de residência, 2008. [acesso em 2014 abr. 16]. Disponível em: http:// tabnet.datasus.gov.br/cgi/sih/nrdescr.htm

6. Graham A, Luber S, Wolfson AB. Urolithiasis in the emergency department. Emerg Med Clin N Am. 2011;29(3):519-38.

7. Netto Jr RN. Litíase urinária. In: Netto Jr RN. Urologia prática. São Paulo: Atheneu; 1999. p.61-80.

8. Soucie JM, Coates RJ, McClellan W, Austin H, Thun M. Relation between geographic variability in kidney stones prevalence and risk factors for stones. Am J Epidemiol. 1996;143(5):487-95.

9. Scales CD Jr, Smith AC, Hanley JM, Saigal CS; Urologic Diseases in America Project. Prevalence of kidney stones in the United States. Eur Urol. 2012;62(1):160-5.

10. Ghani KR, Roghmann F, Sammon JD, Trudeau V, Sukumar S, Rahbar H, et al. Emergency department visits in the United States for upper urinary tract stones: trends in hospitalization and charges. J Urol. 2014;191(1):90-6.

11. Strope SA, Wolf JS Jr, Hollenbeck BK. Changes in gender distribution of urinary stone disease. Urology. 2010;75(3):543-6. 
12. Organização Mundial da Saúde. Classificação estatística internacional de doenças e problemas relacionados à saúde. 10ạ revisão (CID-10). 8a ed. São Paulo: EDUSP; 2000.

13. Barbosa IR, Costa ICC. Distribuição espacial dos casos novos de tuberculose no Estado do Rio Grande do Norte, Brasil. Rev Baiana Saúde Pública. 2013;37(2):452-9.

14. Daudon M, Doré JC, Jungers $P$, Lacour B. Changes in stone composition according to age and gender of patients: a multivariate epidemiological approach. Urol Res. 2004;32(3):241-7.

15. Knoll $T$, Schubert $A B$, Fahlenkamp $D$, Leusmann DB, Wendt-Nordahl G, Schubert G. Urolithiasis through the ages: data on more than 200,000 urinary stone analyses. J Urol. 2011;185(4):1304-11.

16. Nowfar S, Palazzi-Churas K, Chang DC, Sur RL. The relationship of obesity and gender prevalence changes in United States inpatient nephrolithiasis. Urology. 2011;75(5):1029-33.

17. Lieske JC, Peña de la Veja LS, Slezak JM, Bergstralh EJ, Leibson CL, Ho KL, et al. Renal stone ep- idemiology in Rochester, Minnesota: an update. Kidney Int. 2006;69(4):760-4.

18. Kartha G, Calle JC, Marchini GS, Monga M. Impact of stone disease: chronic kidney disease and quality of life. Urol Clin N Am. 2013;40(1):135-47.

19. Trinchieri A, Coppi F, Montanari E, Del Nero A, Zanetti $G$, Pisani $E$. Increase in the prevalence of symptomatic upper urinary tract stones during the last ten years. Eur Urol. 2000;37(1):23-5.

20. Soucie JM, Coates RJ, McClellan W, Austin H, Thun $M$. Relation between geographic variability in kidney stones prevalence and risk factors for stones. Am J Epidemiol. 1996;143(5):487-95.

Received in: 20/06/2016

Accepted for publication: 26/09/2016

Conflict of interest: none.

Source of funding: National Council for Research and Technological Development (PIBIC / UNITAU / CNPq).

\section{Mailing address:}

Luiz Carlos Maciel

E-mail: luizmaciel@uol.com.br / luizmaciel@me.com 